\title{
GENDER-BASED LEGISLATION AND FEMALE LABOR PRODUCTIVITY IN ARGENTINE FACTORIES, 1895-1935
}

\author{
Yovanna Pineda*
}

enviado: Julio 2011- aceptado: Junio 2012

\begin{abstract}
Resumen
Este documento de trabajo examina el género basado en la legislación destinada a proteger a las trabajadoras y limitar sus actividades laborales en la fabricación de las fábricas en la Argentina entre 1895 a 1935. El objetivo es discutir las contradicciones entre la legislación basada en el género y la productividad de la mano de obra femenina. Mi investigación, hasta ahora, muestra que el trabajo femenino era productivo entre los años 1895 y 1935, pese a las leyes restrictivas que limitaron lo que las mujeres podían hacer en la fábrica. Dos consecuencias son que la legislación laboral fue mínimamente o no se aplicaba en las fábricas. En segundo lugar las trabajadoras, en particular las que trabajaban en las fábricas textiles, se centraron en la pieza de trabajo de mano de obra que se completó en su casa y más allá de la legislación protectora.
\end{abstract}

Clasificación JEL: N36

Palabras clave: legislación basada en el género - trabajo femenino - productividad de fabricación

\begin{abstract}
This working paper examines gender-based legislation intended to protect working women and limit their work activities in manufacturing factories in Argentina from 1895-1935. The goal is to discuss the contradictions between gender-based legislation and female labor productivity. My research, thus far, shows that female labor was productive between 1895 and 1935 despite restrictive

\footnotetext{
* University of Central Florida, Department of History, Assistant Professor, Orlando, FL. e.mail: ypineda@ucf.edu
} 
legislation limiting what women could do in the factory. Two implications include that labor legislation was either minimally or not enforced in factories. Second, female laborers, in particular those working in textile factories, focused on labor-intensive piece work that they completed at home and beyond the limits of protective legislation.

JEL Classification: N36

Keywords JEL: gender-based legislation - female labor - manufacturing productivity

\section{INTRODUCCION}

Between the late nineteenth and early twentieth centuries, urbanization, industrialization, and an influx of immigration brought with it rapid social and economic changes, including the growth of Argentina's manufacturing sector. By 1900, Argentina was a major world exporter of grains and linseed. Beginning in this period, manufacturing became the second most important sector of the economy. The government supported developing agro-industries and debated how to protect fledging industries. It raised tariffs on selected imports of manufactured goods, and Congress discussed ways to support the manufacturing sector. By 1914, tariffs on key manufactured consumer products, a rise in the urban labor force, and growing internal markets helped push the growth of the domestic manufacturing sector. By the 1920s, increased mechanization and fluctuating agricultural prices resulted in the migration of rural farmers and peons to the cities, in particular Buenos Aires. As urbanization expanded quickly so did the rise in the industrial labor force.

Among these changes of the early twentieth century, women working in factories became a common sight. Beginning in the late nineteenth century, Argentine female workers contributed to the industrialization processes. They largely occupied secondary jobs ${ }^{1}$. In most cases, secondary jobs discourage stability,

\footnotetext{
${ }^{1}$ The dual labor market theory distinguishes between the primary and secondary job markets. Primary jobs encourage stable working habits. Neoclassical economic theory cannot explain the dual labor market. It is the "historical processes whereby political-economic forces encourage the division of the labor market into separate submarkets, or segments, distinguished by different labor market characteristics and behavioral rules.” Reich et al. 'A Theory of Labour Market Segmentation', American Economic Review, (1973), p. 359.
} 
turnover is high and wages are low. Historically, these latter jobs are nearly exclusively filled by minority workers, women, children, and young adolescents. Most women in Argentina first entered the industrial workforce out of need for income ${ }^{2}$. Immigrant women in particular played a role in helping sustain the family unit between 1890 and $1913^{3}$. In some cases, heads of household expected unmarried female members contribute to sustain the household. Generally, working women turned to factory work because job opportunities for them were limited to low paying domestic work. Factory pay was lower than male wages, but was relatively higher than wages in other commonly female-gendered professions.

Native and foreign born women were a vital labor source in manufacturing. Between 1895 and 1935, female workers were represented in nearly all manufacturing, service, and commercial activities. They were largely working in traditionally female-dominated sectors of textiles, matches, and tobacco, but also worked in metallurgy and paper manufacturing activities. Between 1895 and 1935, women represented between 30 and 75 percent of all workers in the textiles, matches, and tobacco sectors (Table 1). Statistical evidence demonstrates that women's productive contribution was significant, helping these sectors develop.

\section{GENDER-BASED REFORM AND LEGISLATION}

The literature on working class females has been growing to fill a lacuna on Latin American women's labor activities during the industrial movements of the late nineteenth and early twentieth centuries ${ }^{4}$. These studies demonstrate how managers treated working women differently from men and how women's capabilities in the workforce were limited through legislation and societal norms that restricted their independence ${ }^{5}$.

\footnotetext{
${ }^{2}$ Need can be measured by several variables, namely husband's income, number of income earners versus the number of dependents, and women's household status.

${ }^{3}$ Lobato, 'Women Workers in the "Cathedrals of Corned Beef": Structure and Subjectivity in the Argentine Meatpacking Industry', in James and French; The Census of 1914 indicates that 30 percent of the Argentine population was foreign born. Censo 1914 (1917).

${ }^{4}$ For instance the works of Mirta Zaida Lobato, including Historia de las trabajadoras en la Argentina (1869-1960) (Buenos Aires: Edhasa, 2007) and "La mujer trabajadora en el siglo XX: un estudio de las industrias de la carne y textile en Berisso, Argentina.” In Lobato, Mirta Zaida, Eliana Villar Márquez et al. Mujer, trabajo, ciudadanía (Buenos Aires: Gráficas y Servicios, 1995).

${ }^{5}$ Ivy Pinchbeck's $(1930,1969)$ seminal work on British working women was among the first pieces to focus on female factory workers during the industrial revolution of England. Since then, there have been a growing number of works examining working women's lives.
} 
Argentine reformers and socialists viewed factory women as victims of modern urbanization and industrialization rather than victims of job discrimination. In the early twentieth century, reformers often described working women as victims of industry bound to low wages, exposed to disease, and restricted from tending to their small children. Women were also believed to be more susceptible to immoral and potentially criminal behavior if exposed to it in the streets of the cities $^{6}$. At times, reformers addressed the specific problems facing women such as lower pay for the same work males were doing. Physician Juan Bialet Massé, for instance, recognized that working women should receive equal pay for the same work as men. In 1904, Bialet Massé, wrote on the egregious inequality in daily wages between young girls and men in Córdoba who were performing similar factory tasks ${ }^{7}$. Despite his attention to the issue of unequal wages, he ultimately believed that women should not work outside the home and his concern was not disrupting women's ability to reproduce ${ }^{8}$.

Ultimately, among the authorities there were contradictions among the beliefs about gender-based legislation, women's role in society, women's work, and motherhood. On the one hand, Argentine socialists explicitly stated that a woman's "supreme mission" was to be a mother and that married women "should never work outside the home" . On the other hand, as authors Marcela Nari (Argentina), Christine Ehrick (Uruguay), and Susan Besse (Brazil) have pointed out authorities didn't create laws prohibiting women from working ${ }^{10}$. Although it was considered "unfortunate" that women had to perform labor outside the home, it was considered a necessary function for poor family households. In most cases, in the early twentieth centuries, government authorities in South American countries created gender-based legislation, a form of state-sponsored paternalism that "protected" women while at the same time failing to challenge established societal norms of

\footnotetext{
${ }^{6}$ Kristin Ruggiero, Modernity in the Flesh (chapter 1) (Stanford, Calif.: Stanford University Press)

${ }^{7}$ Bialet Massé. Informe sobre el estado de las clases obreras en el interior de la república. Vol. 2. (Buenos Aires: Imprenta y Casa Editora de Adolfo Grau, 1904), 362.

${ }^{8}$ He writes, "after an 11 hour shift seated at the assembly line, how is her uterus? ... [She] is as a beast burdened by wages and misery.” Bialet Massé, Informe, 362.

${ }^{9}$ A. H. Varela, El Nacionalismo argentino y los obreros socialistas (Buenos Aires: Imprenta López, 1935), 169-174.

${ }^{10}$ Marcela Nari, Políticas de maternidad y maternalismo político (Buenos Aires: Editorial Biblos, 2004); Christine Ehrick, "To Serve the Nation: Juvenile Mothers, Paternalism, and State Formation in Uruguay, 1910-1930,” Social Science History, Vol. 29, no. 3 (2005), pp. 489-518; Susan K. Besse, Restructuring Patriarchy: The Modernization of Gender Inequality in Brazill, 1914-1940 (Chapel Hill and London: University of North Carolina Press, 1996).
} 
gender inequalities. Beginning in 1907, socialist deputy, Alfredo Palacio, for instance, was a leading proponent for the protection of factory women. He called for legislation to help female workers from the "exploitation, subordination, and risks of factory life" by allowing them more time to be mothers during factory hours ${ }^{11}$.

How did women work in factories and remain good mothers during work hours? In the early twentieth century, protective legislation in Argentina was largely influenced by European gender-based codes. In the late nineteenth century, social reformers in England, France, Germany and Belgium debated reforms to protect child and female factory labor ${ }^{12}$. In 1906, international legislation signed by thirteen industrialized countries prohibited night work in industrial employment for all women ${ }^{13}$. Other reforms called for maternity benefits, shorter hours, and longer breaks for female and child workers. As a late industrializing country, Argentina willingly followed this committee's model, and passed Law 5,291 of 1907 that prohibited night work for women and children. The purpose of this law was to prevent abuses observed in European industrial factories.

A second law repealing the 1907 law was 11317 of 1924; it was geared toward increasing the protection of women and minors. It stipulated that women and minors must be given a two-hour lunch break. Women were limited to eight hour work days and forty-eight per week, and minors were limited to six hours per day and thirty-six per week ${ }^{14}$. This same law also protected maternal rights and mandated that nursing mothers take rests every three hours to feed small children. Under the labor laws of 1924 and 1932, managers would have been expected to increase women's breaks at the factory and contribute to a maternity fund ${ }^{15}$. Women

\footnotetext{
${ }^{11}$ Bellucci and Camusso, La huelga de inquilinos de 1907 (Buenos Aires: Centro de Investigaciones en Ciencias Sociales, 1987), 24.

${ }^{12}$ Mary Lynn Stewart, Women, Work, and the French State: Labour Protection and Social Patriarchy, 1879-1919. (Montreal: McGill-Queen’s University Press, 1989).

13 "International Convention Respecting the Prohibition of Night-Work for Women in Industrial Employment,” Berne, September 26, 1906. Reprinted in United States, War Labor Policies Board, Report on international labor standards (1919), 81-83.

${ }^{14}$ Law 11371 of 1924 replaced law 5291 of 1907, prohibiting women and minors from working night shifts and setting the minimum work age to ten. Law 11371 also increased the working age from ten to twelve and set literacy requirements. Law 5291 is reprinted in Matilde Alejandra Mercado, $\mathbf{L a}$ primera ley de trabajo femenino, "La mujer obrera” (1890-1910) (Buenos Aires: Centro Editor de América Latina, 1988), 72-74.

15 'Maternity leave laws give women 30 days before and 45 days after childbirth, with a total allowance equal to $2 \frac{1}{2}$ months' pay at the rate of 25 working days a month, up to a fixed maximum benefit. The law also prohibits married and pregnant women from being discharged. In Argentina, a maternity fund
} 
were also restricted from working in any area considered dangerous or toxic and they were prohibited from operating machinery ${ }^{16}$.

Although the intent of gender-based legislation was to shield women from abuses in the factory, these codes also restricted women's roles in the workforce. Gender-based laws reinforced the patriarchal notion that women needed to be defended from society. Women were viewed as being unintentionally removed from their natural role as mothers and wives and forced to work in a factory. Codes did not appreciate women as long-term factory workers worthy of being trained on machinery and competing with male workers for higher wages and supervisory roles. Quite the contrary, laws prohibiting night work for women, for instance, eliminated opportunities to become supervisor because such a position required flexibility and ability to work after 8:00PM. Moreover, single women without children did not directly benefit from these laws. The allowances for longer breaks and maternity leave were specifically directed for women with children. For the most part, protective legislation failed to address the overall problems that female labor faced in the workforce such as limited promotion, low wages, little machine training, forced industrial home work, and sexual harassment.

Gender-specific legislation was intended to protect the family, restrict women's mobility, and ensure that men remained dominant in the workforce. An implicit fear that women would find work easier than men underlined Congressional debates because women were paid significantly less than males. Perhaps the Argentine government sought to ensure male employment by reducing the competition from female labor. The protective code lessened women's ability to effectively compete with male workers. In 1924, the industrial lobby, Unión Industrial Argentina (UIA), argued against the Law of 1924 because the increased number of breaks disrupted the "order and routine" of the factory schedule, and hiring women would be less convenient to factory owners ${ }^{17}$. UIA threatened that women would be less likely to be hired because of these labor laws, and that more

is maintained by a tax paid by each employed woman on her wages, by a tax paid by the employer on the pay rolls of women employees, and by a contribution from the state. Members of a textile union in Buenos Aires have asked various women's organizations to consider with them changes in the maternity-fund law, such as the inclusion of women on the board of directors, and methods of giving benefits so that they will be used for the purpose for which they are intended'. (U.S. Women Workers in Argentina, Chile and Uruguay, p. 10).

${ }^{16}$ Article 11 lists activities where working women are prohibited: shipping, mining, construction, machinist (machine operator), working with weapons, cleaning machinery while in motion, tinting and leatherworking, glassblowing, blacksmithing, etc. Law 11317 of 1924.

${ }^{17}$ Nari, Políticas de maternidad, 217. 
expensive adult male labor would be hired to replace women and minors ${ }^{18}$.In the case of the UIA, they were more concerned about the rationalization of maintaining women as a productive and cheap labor force rather than replacing them with expensive male labor.

The government, lobby groups, and other institutions did not dispute that women were productive and dominating certain industrial sectors. But they wanted to control female labor and restrict them to certain labor-intensive activities. Census data between 1895 and 1935 indicate that the number of female workers increased in textile, tobacco, and match factories. By the 1920s, women started working in the male-dominated sectors of paper and metallurgy. Their productive contribution helped in the overall development of these sectors. If the labor market had been fair, women in female-dominated sectors should have received adequate compensation through higher wages and promotion. Instead women were marginalized in the lowest paying jobs and were limited in their ability to achieve economic emancipation.

The sexual division of labor in the factories relegated women to the lowest paying and most rudimentary tasks in the factory. Given Argentine women's high productivity levels, managers could have used female labor more effectively by training women on machinery or creating incentives through higher wages. But women often received lower wages than males and were excluded from higher paying jobs and supervisory roles. Women's exclusion from better paying positions could be partly blamed on discriminatory practices such as managers' preferences for male workers and the exclusion of women in male unions. Argentina's protective laws reinforced these discriminatory practices. The intent behind Argentina's protective laws was to defend women's role as mothers and wives, and not to guard their right to work. Between 1933 and 1934, socialist senators Alfredo Palacios and Mario Bravo continued congressional debates on women's roles in the factory. They demanded greater protection of factory women's right to motherhood and demanded larger infractions against factory owners who failed to comply with the law. The bill included creating a "mother fund" for women on pregnancy leave ${ }^{19}$. Although the intent was to protect women, it was also highly

\footnotetext{
${ }^{18}$ UIA argued that the minor age should be lowered to fourteen. Unión Industria Argentina, "Observaciones expresadas al P. E., Octubre 10, 1924, al Excmo. Sr. Ministro del interior, Dr. Vicente C. Gallo, Ley de trabajo de mujeres y menores,” in Anales de la Unión Industrial Argentina, Vol. 38, no. 670 (October 15, 1924), 35-37.

19 "Proyecto de los senadores Palacios y Bravo sobre seguro a la maternidad,” (7 Sep. 1933), p. 42. In Diario de sesiones de la Cámara de Senadores, periodo ordinario, Vol. 2, 5-30 de Sep. 1933. (Buenos Aires: Publicación del Cuerpo de Taquigrafos del Senado de la Nación, 1934).
} 
patriarchal and limited women to the lowest paying jobs in the factory; they were prohibited from operating machinery and working in so-called "dangerous" activities. Consequently, they received low paying labor-intensive positions with limited or no opportunity for promotion.

\section{FEMALE LABOR PRODUCTIVITY}

Despite protective legislation limiting women's roles in manufacturing factories, statistical data on labor across time demonstrate that female labor made a significant productive contribution in Argentina's manufacturing factories. Women's productive contribution was clear in the female-dominated sectors of matches, textiles, and tobacco. They represented between 33 and 74.1 percent in these activities in the census years of 1895, 1914 and 1935 (Table 1). In these sectors, there is overall growth to labor productivity between the censuses of 1895 and 1935 (Table 2). The most impressive increases in female labor productivity are in textiles production wherein productivity increased by nearly three times (Table 2). Women also contributed to production in traditional male sectors, such as iron and steel manufacturing between 1895 and 1935. By 1935, women represented 31.6 percent of the labor force in iron and steel production (Table 1). Because Argentine manufacturing remained relatively labor-intensive through most of the twentieth century, female labor remained important and dominated in labor-intensive tasks. Increases to female labor productivity were likely due to increased work intensity while in the factory, piece work ${ }^{20}$, and longer hours by taking work home.

Female wages remained low throughout the period under study and fail to reflect women's high productivity levels. Female compensation remained significantly lower than male wages. In 1904, the Buenos Aires municipal census reported labor statistics including wages and hours worked. Women consistently had lower daily wages than males within six female-dominated activities (Table 3). Depending on task, the majority of women received less than 0.50 and up to 3 pesos (nominal paper pesos) per day. Most men, on the other hand, were paid between 2 and 5 pesos daily. In regards to hours worked, all laborers worked on

\footnotetext{
${ }^{20}$ Frederick W. Taylor popularized a process of labor discipline based on scientific management to ensure human efficiency. Among his incentive systems was to 'devise wages scales based on piece work, such that the productive worker shared in the expansion of output, but would fall below a subsistence wage and be forced to quit if inefficient.' Maier, 'Between Taylorism and Technocracy', 29.
} 
average nine hours per day ${ }^{21}$. About 37.3 percent of workers in the city regularly worked on Sundays ${ }^{22}$. Longer hours were particularly important in the labor-intensive divisions of the factory.

In 1935, the Argentine Department of Labor published their national statistics on female and child labor in the textiles sector. The Department's results demonstrated that little had changed in the textiles sectors in terms of high female productivity and low wages. Between 1929 and 1935, labor productivity continued to rise, yet women earned on average between 60 and 69 percent of male wages (Table 4).

The Department indicated that machine use was decreasing in the textiles sector, indicating that labor-intensive tasks ("women's work") were pushing the sector's productivity levels. Women increased their productivity through increased work intensity while on the shop floor and longer hours by taking work home. The Department attributed the decline of machine use to a greater increase of breakdowns. Although this is likely the case, it could also be that females were never trained to use the machines and therefore machines remained idle.

\section{IMPLICATIONS OF FEMALE LABOR AND LEGISLATIVE RESTRICTIONS}

Managers viewed female and child labor as a cheap source to be exploited through low wages and long hours ${ }^{23}$. Unlike a male worker who typically had strong union representation, a female worker was more susceptible to being easily fired. All industries had labor-intensive tasks that were customarily given to women and children as they were considered ideal for unskilled jobs. Regardless of protective laws, owners easily exploited female labor through home and piece rate work. Gender-specific labor laws largely enforced the assignment of women to lower paying activities in the factory. Women were quite vulnerable in the factory because they were never trained in high skilled positions. Managers hired

\footnotetext{
${ }^{21}$ In a municipal study of average hours worked per worker in 1904, 7,323 establishments of the industries under study stated that 97.8 percent of their workers laboured between eight to ten hours per day. 'Horas de trabajo en los establecimientos industriales', in Buenos Aires (Argentina). Dirección general de estadística municipal, Censo general de población, edificación, comercio é industrias de la ciudad de Buenos Aires (Buenos Aires: Cía Sud-Americana de billetes de Banco, 1906).

22 'Horas de trabajo en los establecimientos industriales'

${ }^{23}$ Belluci and Camusso, La huelga de inquilinos de 1907, 22-23.
} 
women because they could be easily fired and replaced with other women willing to do the low skill, labor-intensive duties. Managers could also increase female productivity through labor speed-ups, longer hours, increased work intensity, and forcing them to take work home.

Factories managers hired women not just because they were inexpensive labor but rather they were also good workers. Economic data show that women significantly contributed to factory production. Like men, women played a significant role in industry beginning in the late nineteenth century. The data on female labor productivity and wages implied that the extent of the costs and benefits of the sexual division of labor were unequally shared between men and women, to the patent disadvantage of the latter.

How did working women adapt to job discrimination and factory life? Oral histories of Argentina's working women demonstrate how they publicly accepted their worker status as a subsidiary wage earner ${ }^{24}$. Working women used the language of motherly duty, as supplied to them by the legislators, Catholic elite, and protectors to justify their work outside the home ${ }^{25}$. They used this language as the life script to justify their working lives. Women constructed new feminine identities to deal with the paradoxes of the social expectations to stay in the home and the realities that they must work to support the household. By the 1920s, women who organized did so under the guise that as mothers they were responsible for the welfare of their families. They developed a language that justified their role in the workplace, but did not disrupt societal norms.

\footnotetext{
${ }^{24}$ John D. French and Daniel James, editors. The Gendered Worlds of Latin American Women Workers: From Household and Factory to the Union Hall and Ballot Box (Duke University Press, 1997).

${ }^{25}$ Also see Hutchinson, Labours Appropriate to their Sex: Gender, Labour, and Politics in Urban Chile, 1900-1930 (Durham: Duke University Press, 2001), 9.
} 
$\sum_{10}^{\pi}$

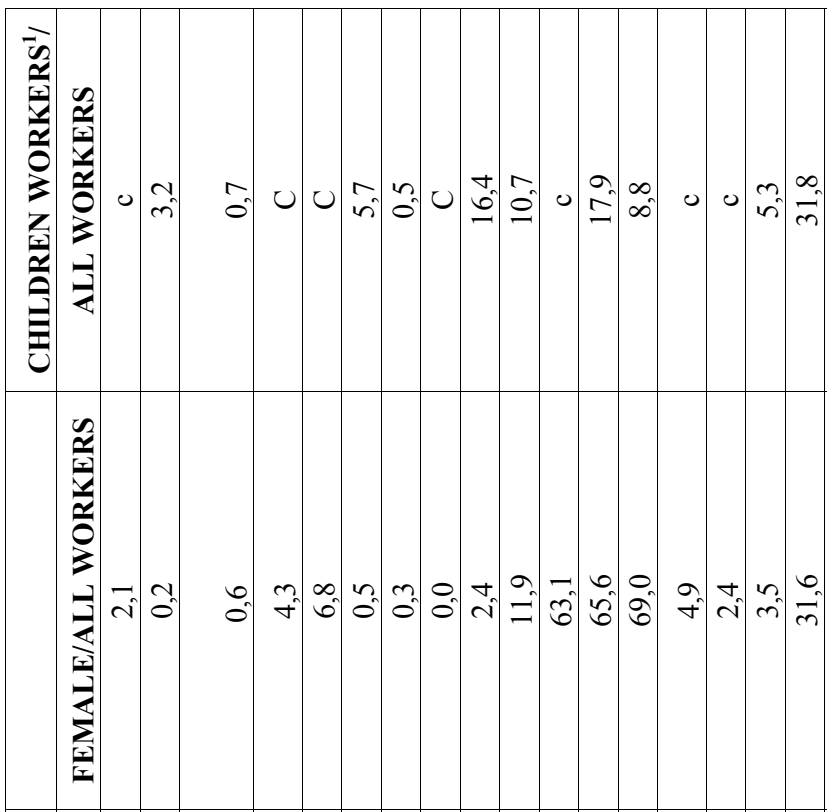

ก

흐

Чั

\&

a

름

ปัป

ต

की

을

3

듬

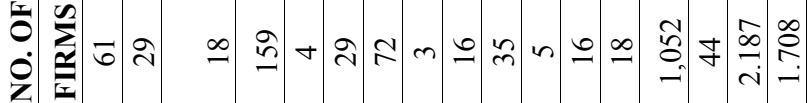

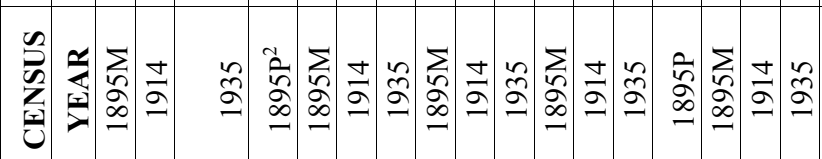

큼

음

밍

ت.

$\frac{0}{0}$

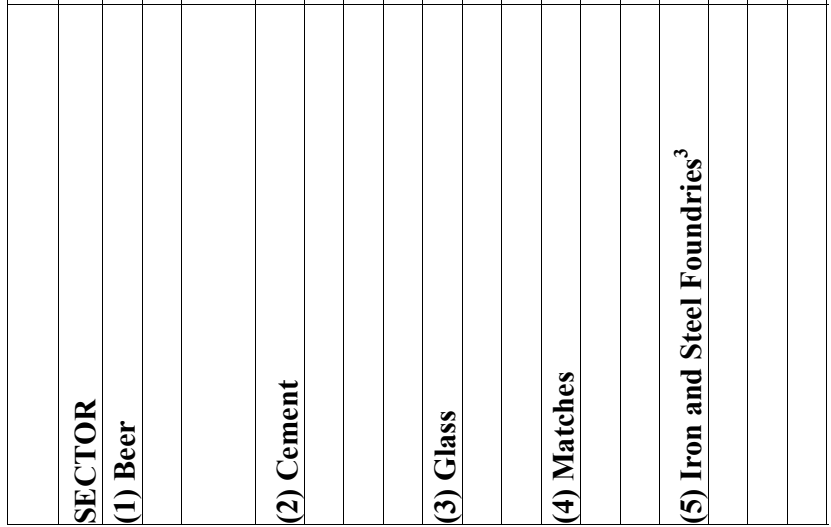




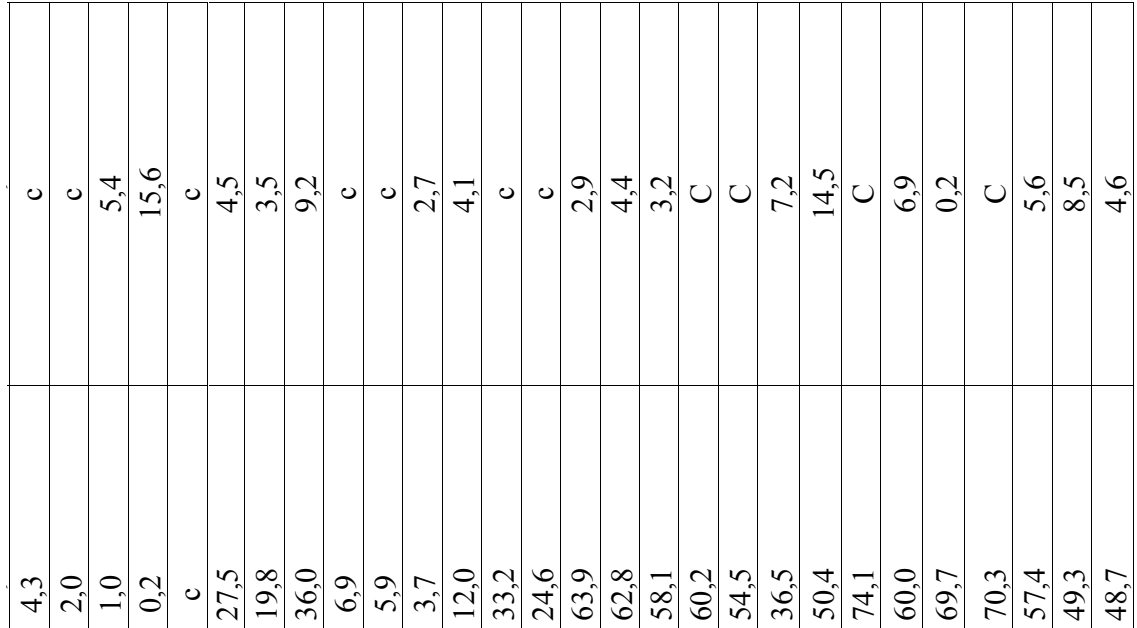

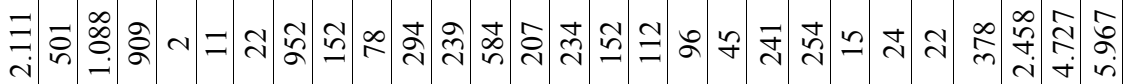

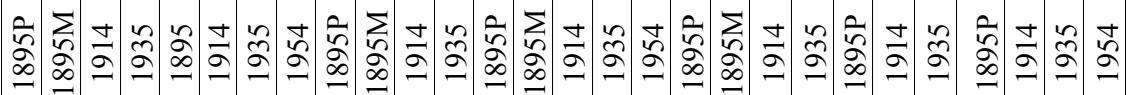
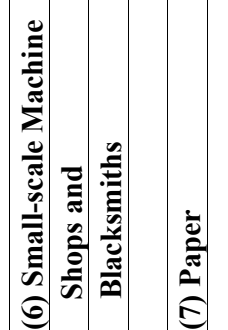

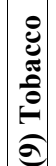

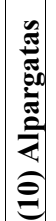

ฮับ 


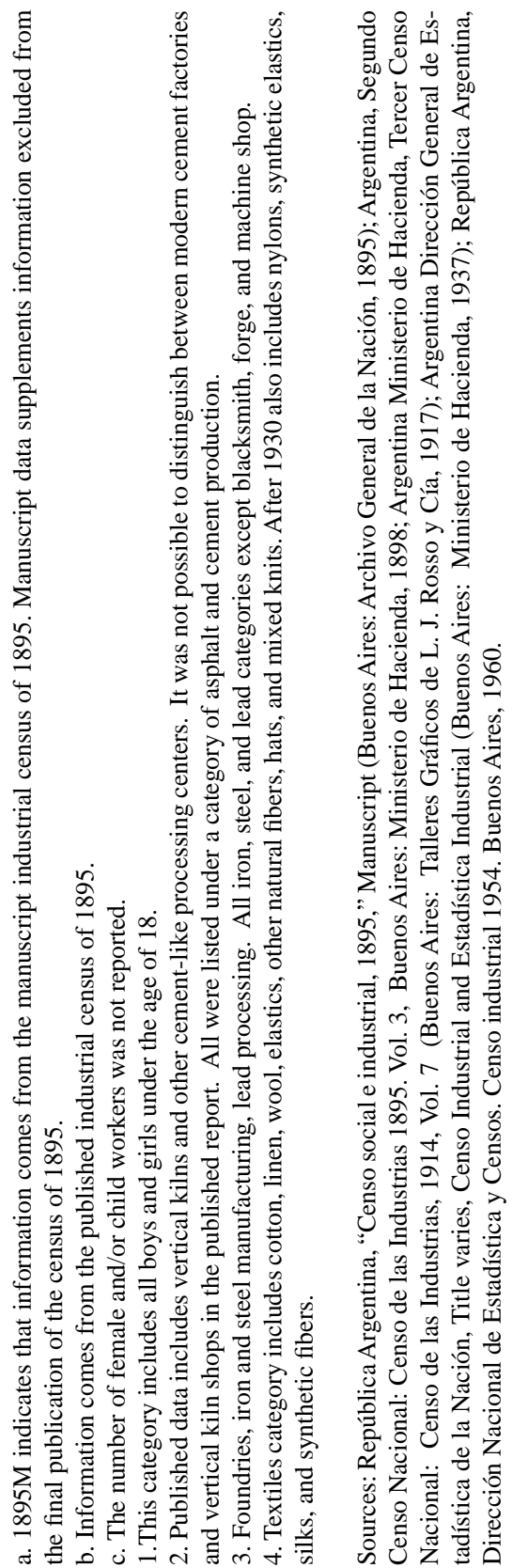




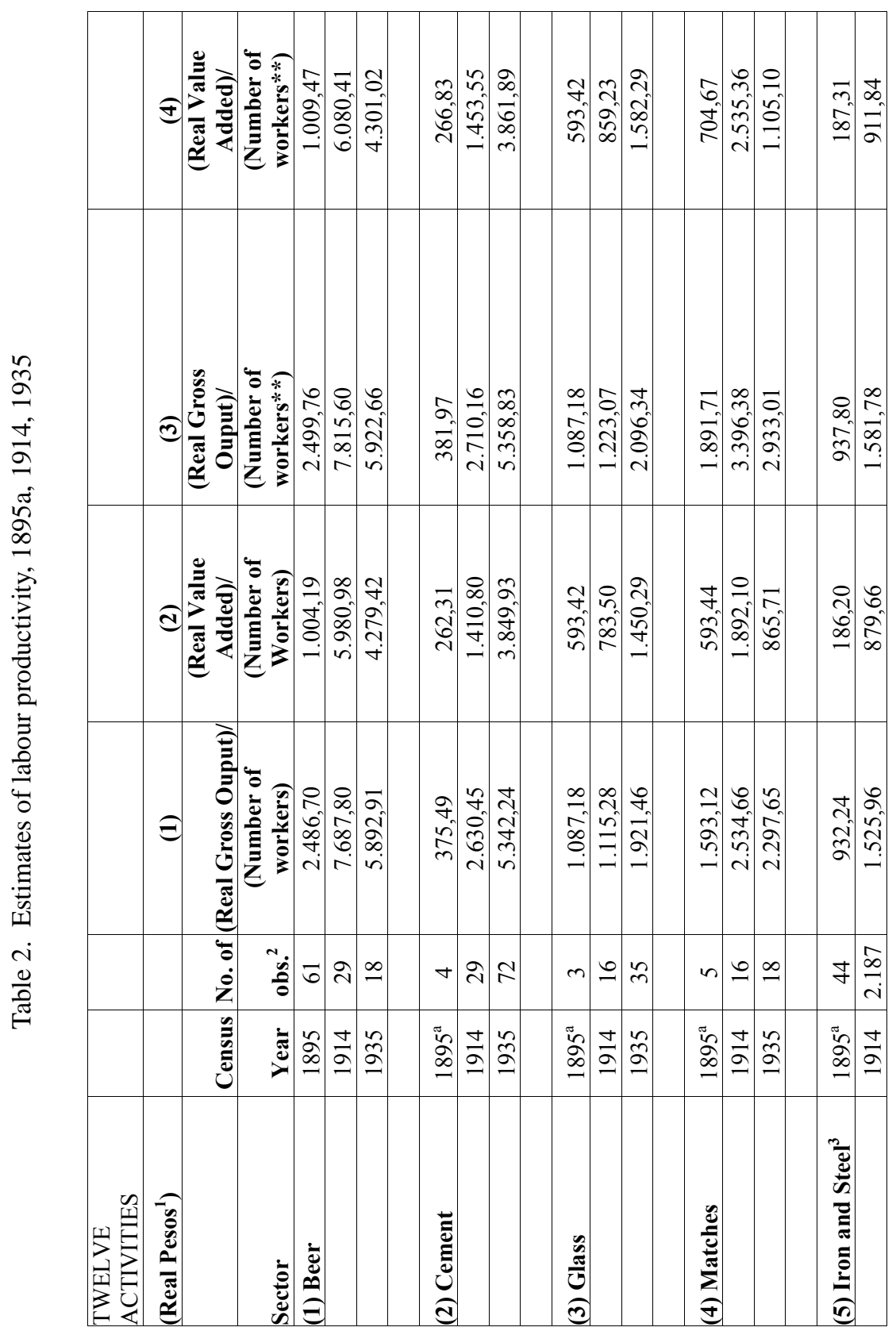




\begin{tabular}{|c|c|c|c|c|c|c|c|c|c|c|c|c|c|c|c|c|c|c|c|c|}
\hline $\begin{array}{l}a \\
\dot{y} \\
\tilde{n} \\
\sigma \\
\end{array}$ & $\begin{array}{l}\text { bु. } \\
\infty \\
0 \\
0 \\
0\end{array}$ & 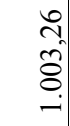 & 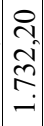 & مـ & $\begin{array}{c}\mathfrak{n} \\
\hat{\mathfrak{a}} \\
\end{array}$ & 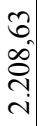 & $\begin{array}{l}n \\
0 \\
0 \\
0 \\
\end{array}$ & 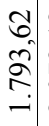 & $\begin{array}{c}v \\
\tilde{N} \\
0 \\
\dot{0} \\
\sim\end{array}$ & $\begin{array}{l}N \\
\infty \\
m \\
m\end{array}$ & 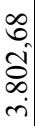 & 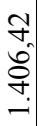 & 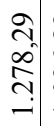 & 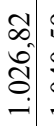 & 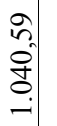 & 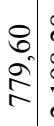 & 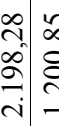 & $\begin{array}{l}\hat{0} \\
\text { fo }\end{array}$ & & $\begin{array}{l}\infty \\
\infty \\
0 \\
\infty \\
\infty \\
-\end{array}$ \\
\hline $\begin{array}{c}\tau \\
\delta \\
\dot{T} \\
\vec{t} \\
\dot{0} \\
-\end{array}$ & $\begin{array}{l}\hat{n} \\
\hat{n} \\
n\end{array}$ & 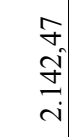 & $\mid \begin{array}{c}n \\
n \\
n \\
m \\
n \\
n\end{array}$ & 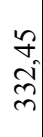 & $\left|\begin{array}{c}0 \\
\infty \\
\infty \\
n \\
\sim \\
v\end{array}\right|$ & 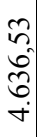 & $\begin{array}{l}\hat{n} \\
\swarrow \\
n \\
\\
i\end{array}$ & $\begin{array}{l}F \\
\vec{f} \\
2 \\
\infty \\
\dot{n} \\
.\end{array}$ & $\begin{array}{c}\text { I } \\
n \\
\hat{0} \\
a \\
0\end{array}$ & $\begin{array}{l}0 \\
\infty \\
i \\
\infty\end{array}$ & 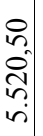 & 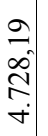 & $\begin{array}{l}1 \\
\tilde{2} \\
\tilde{n} \\
0 \\
-i\end{array}$ & 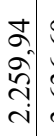 & 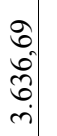 & & 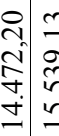 & $\begin{array}{l}\sigma \\
= \\
= \\
= \\
-1\end{array}$ & 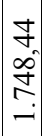 & \begin{tabular}{l}
8 \\
$\dot{0}$ \\
\multirow{n}{n}{} \\
$n$ \\
$n$
\end{tabular} \\
\hline $\begin{array}{l}2 \\
\infty \\
\dot{0} \\
0 \\
\dot{0}\end{array}$ & 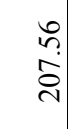 & 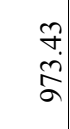 & $\begin{array}{c}\vec{n} \\
0 \\
2 \\
n \\
-1\end{array}$ & مـ & $\mid \begin{array}{c}0 \\
+ \\
2 \\
2 \\
\beth \\
-1\end{array}$ & 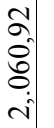 & 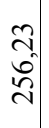 & $\begin{array}{l}= \\
\tilde{n} \\
\stackrel{n}{-}\end{array}$ & $\begin{array}{c} \pm \\
0 \\
\infty \\
0 \\
0 \\
- \\
-1\end{array}$ & $\begin{array}{l}\dot{\sigma} \\
\frac{\infty}{m}\end{array}$ & 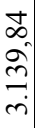 & 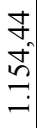 & 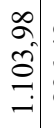 & \begin{tabular}{l}
$\infty$ \\
\multirow{6}{*}{} \\
$\stackrel{0}{\infty}$
\end{tabular} & $\begin{array}{l}\stackrel{2}{2} \\
\hat{\infty}\end{array}$ & $\begin{array}{l}2 \\
\hat{\Sigma} \\
\hat{\Sigma}\end{array}$ & 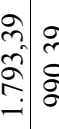 & 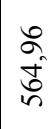 & 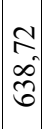 & $\begin{array}{l}\tilde{J} \\
\tilde{n} \\
\stackrel{0}{0} \\
\dddot{n}\end{array}$ \\
\hline $\begin{array}{l}\hat{\alpha} \\
\hat{\hat{s}} \\
0 \\
\dot{\Xi}\end{array}$ & $\begin{array}{l} \pm \\
\hat{a} \\
\tilde{n} \\
n\end{array}$ & 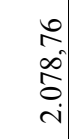 & $\begin{array}{c}N \\
\tilde{n} \\
\infty \\
\stackrel{+}{+} \\
\dot{\sim}\end{array}$ & $\begin{array}{l}\stackrel{n}{f} \\
\stackrel{5}{n} \\
\tilde{n} \\
m\end{array}$ & 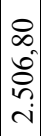 & 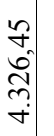 & 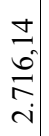 & $\begin{array}{c}\overrightarrow{6} \\
6 \\
+ \\
i \\
i\end{array}$ & \begin{tabular}{l}
$\stackrel{ }{N}$ \\
$\hat{N}$ \\
\multirow{n}{\infty}{} \\
$\infty$
\end{tabular} & 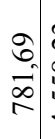 & 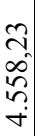 & $\begin{array}{c}\stackrel{0}{0} \\
\dot{0} \\
\dot{\infty} \\
\infty \\
\dot{m}\end{array} \mid$ & $\begin{array}{l}\bar{\sigma} \\
g \\
\text { gे } \\
\stackrel{-}{-}\end{array}$ & 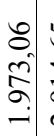 & $\begin{array}{l}\tilde{\sigma} \\
\dot{J} \\
\sigma \\
\dot{v}\end{array}$ & $\begin{array}{l}0 \\
n \\
\curvearrowleft \\
\infty \\
r\end{array}$ & \begin{tabular}{l|l}
$\delta$ & $\alpha$ \\
0 & 1 \\
0 & $n$ \\
$\delta$ & $\alpha$ \\
$=$ & 2
\end{tabular} & 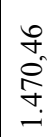 & 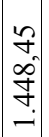 & 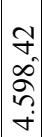 \\
\hline 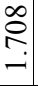 & 음 & $\begin{array}{l}\infty \\
\infty \\
0 \\
0\end{array}$ & ஓे & $\because$ & 二 & N & $\stackrel{\infty}{\sim}$ & ¿े & సิ & $\hat{\mathrm{N}}$ & ָे & กิ & $\stackrel{n}{\sim}$ & $\vec{J}$ & $\stackrel{ \pm}{\sim}$ & in & $\stackrel{\Delta}{\sim}$ & $\stackrel{i}{i}$ & $\left|\begin{array}{c}\infty \\
\stackrel{2}{2} \\
\stackrel{\sim}{v}\end{array}\right|$ & $\stackrel{N}{\widetilde{N}}$ \\
\hline$\tilde{\Omega}$ & $\stackrel{2}{2}$ & $\stackrel{\Xi}{\Xi}$ & $\begin{array}{l}n \\
\tilde{2}\end{array}$ & $\begin{array}{l}\text { in } \\
\infty \\
\infty \\
-1\end{array}$ & $\frac{\nabla}{2}$ & $\tilde{\sigma}$ & $\begin{array}{l}\stackrel{\tilde{n}}{\curvearrowright} \\
\infty\end{array}$ & $\stackrel{\nabla}{\vec{\sigma}}$ & $\tilde{\sigma}$ & $\begin{array}{l}\tilde{a} \\
2 \\
\infty\end{array}$ & $\stackrel{ \pm}{\Xi}$ & $\tilde{\tilde{\sigma}}$ & $\begin{array}{l}\tilde{a} \\
2 \\
\infty\end{array}$ & $\stackrel{\nabla}{\sigma}$ & $\tilde{\sigma}$ & $\begin{array}{l}\tilde{n} \\
\infty\end{array}$ & 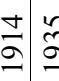 & $\begin{array}{l}\tilde{n} \\
\infty \\
\infty\end{array}$ & $\stackrel{\nabla}{\Xi}$ & $\tilde{2}$ \\
\hline & 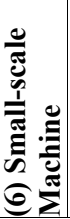 & 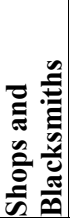 & & 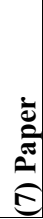 & & & 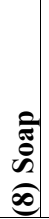 & & & 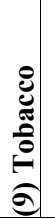 & & & 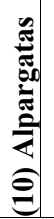 & & & 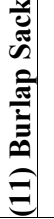 & & 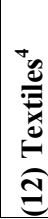 & & \\
\hline
\end{tabular}


ESTUDIOS ECONOMICOS

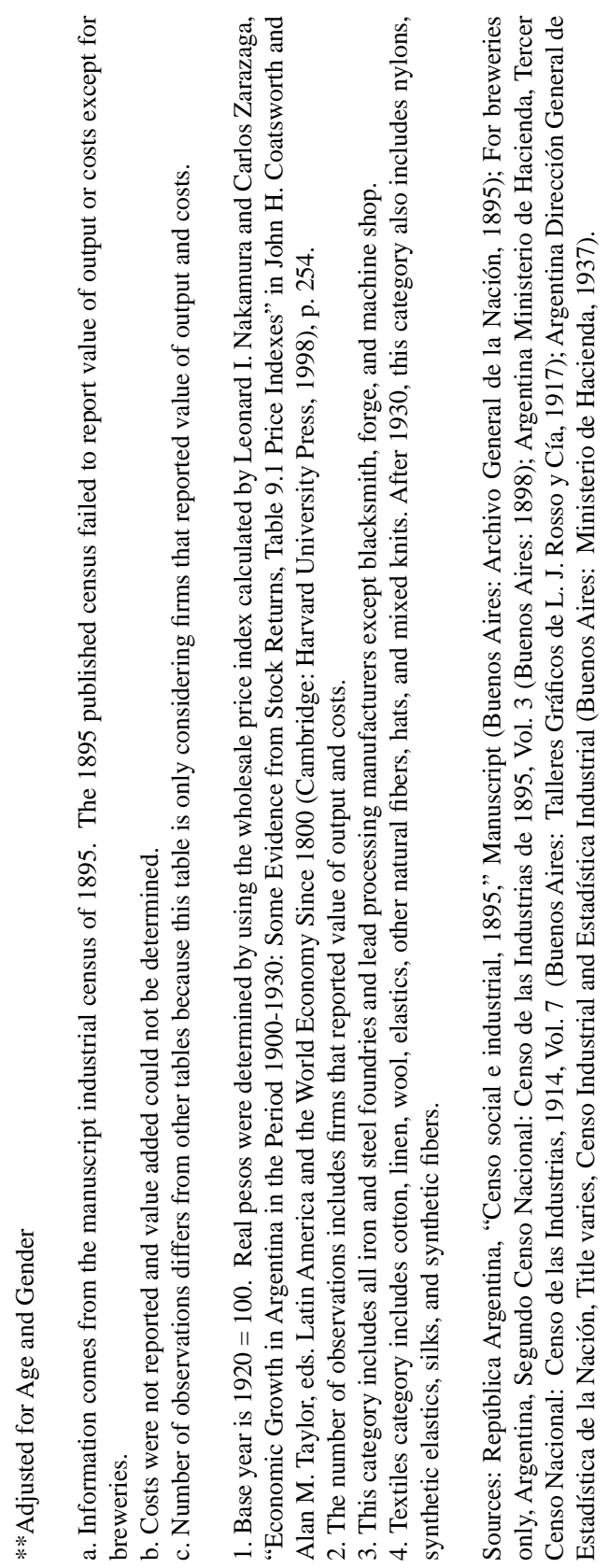


ป

$\stackrel{\mathscr{e}}{=}$

尺े

䓀

.ृ.ّ

苞

छ क

च

菉

灵 즘

킁 응

윰 중

党 㝋

屯苞

믈

可

훙 움

曲

o

3

|

\begin{tabular}{|c|c|c|}
\hline$\sum^{0} \infty$ & 0 & 0 \\
\hline 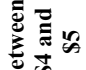 & तु & $\begin{array}{c}n \\
m\end{array}$ \\
\hline
\end{tabular}

\begin{tabular}{|c|c|c|}
\hline 总芯 & 6 & $m$ \\
\hline 要 芯 & $\begin{array}{l}0 \\
0 \\
i\end{array}$ & $\stackrel{N}{N}$ \\
\hline
\end{tabular}

ह

$\oplus \tilde{\omega}$

ह

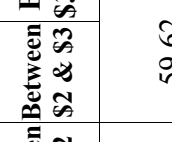

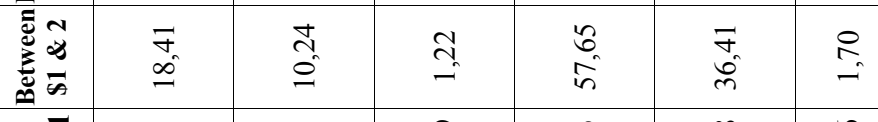

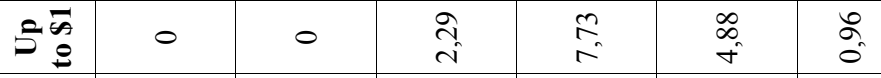

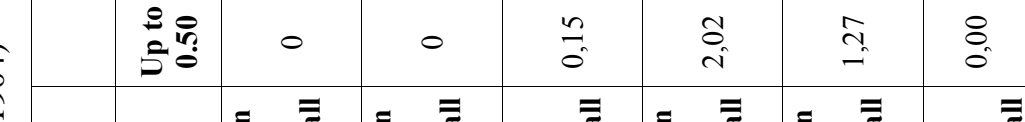

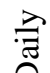

ซ్ర

:

$\dot{1}$

$\frac{0}{\frac{\pi}{0}}$

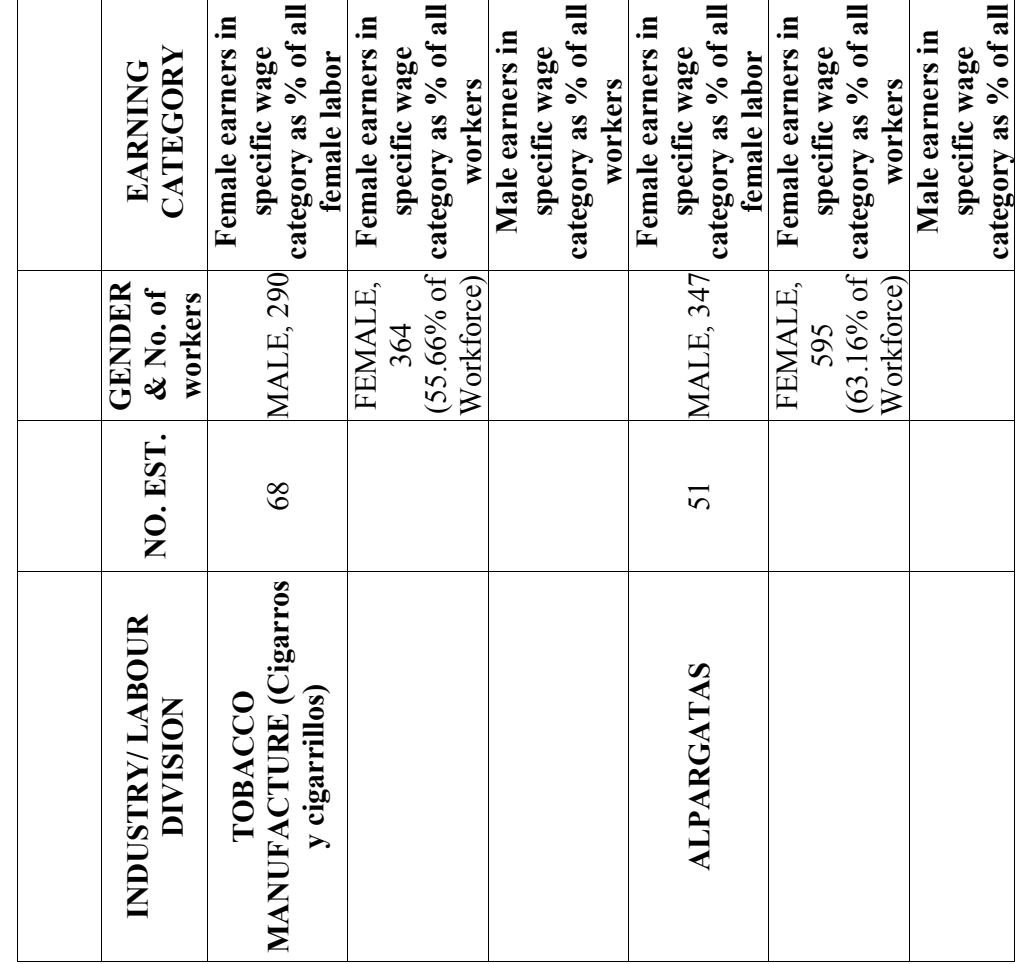


ESTUDIOS ECONOMICOS

\begin{tabular}{|c|c|c|c|c|c|c|c|}
\hline \multirow{11}{*}{ 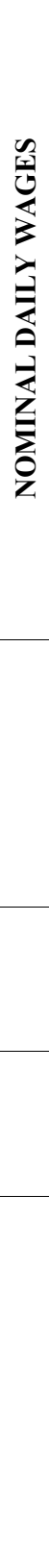 } & $\sum_{n}^{0}$ & 0 & 0 & $\begin{array}{l}\infty \\
\infty \\
0\end{array}$ & 0 & 0 & $\frac{\infty}{m}$ \\
\hline & 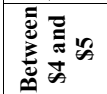 & กู & ñ & $\begin{array}{l}n \\
\tilde{n} \\
\dot{n}\end{array}$ & 0 & 0 & $\begin{array}{l}n \\
i\end{array}$ \\
\hline & 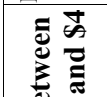 & $\begin{array}{l}8 \\
\because\end{array}$ & $\frac{\mathbb{N}}{\infty}$ & $\begin{array}{l}\infty \\
\stackrel{0}{0} \\
\text { i }\end{array}$ & m. & $\begin{array}{l}n \\
\infty \\
0\end{array}$ & $\begin{array}{l}0 \\
n \\
n\end{array}$ \\
\hline & 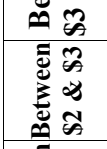 & $\begin{array}{l}\text { ర్ } \\
\text { ฉn }\end{array}$ & $\frac{\infty}{m}$ & $\vec{n}$ & 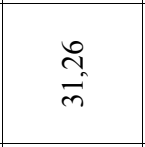 & $\frac{n}{a}$ & $\stackrel{n}{\simeq}$ \\
\hline & $\begin{array}{l}\bar{d} \\
\infty \\
\infty \\
\infty\end{array}$ & $\begin{array}{l}\vec{\sigma} \\
\infty\end{array}$ & 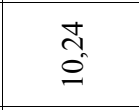 & กี & $\begin{array}{l}n \\
i n \\
i n\end{array}$ & 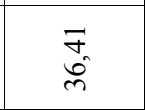 & $\stackrel{2}{\approx}$ \\
\hline & $\tilde{\sigma} \bar{\theta}$ & 0 & 0 & ते & $\stackrel{m}{2}$ & $\begin{array}{l}\infty \\
\infty \\
+\end{array}$ & ஃ. \\
\hline & 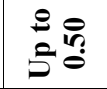 & 0 & 0 & $\frac{n}{0}$ & $\begin{array}{l}\text { ป } \\
\text { i }\end{array}$ & $\cong$ & $\begin{array}{l}8 \\
0\end{array}$ \\
\hline & 文苍 & 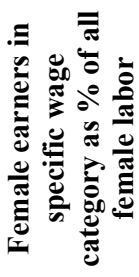 & 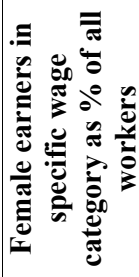 & 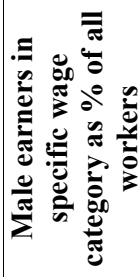 & 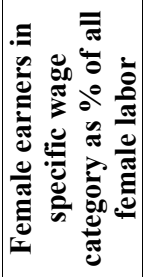 & 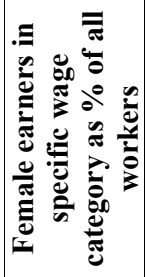 & 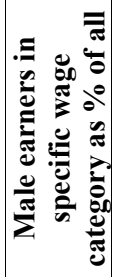 \\
\hline & 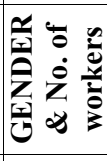 & 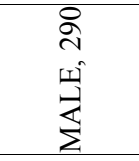 & 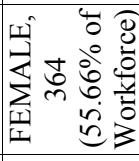 & & 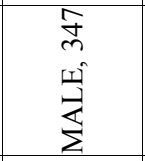 & 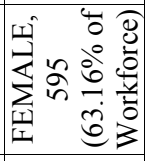 & \\
\hline & $\begin{array}{l}\dot{\theta} \\
\dot{0}=1 \\
\dot{0} \\
\dot{Z}\end{array}$ & $\underset{0}{\infty}$ & & & $\bar{n}$ & & \\
\hline & 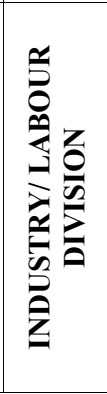 & 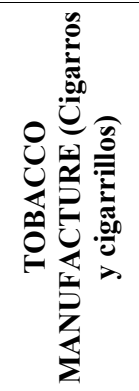 & & & 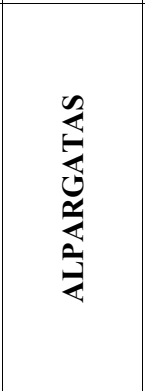 & & \\
\hline
\end{tabular}




\begin{tabular}{|c|c|c|c|c|c|c|c|}
\hline & 0 & 0 & 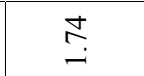 & 0 & 0 & $\begin{array}{l}8 \\
0\end{array}$ & $\begin{array}{l}\infty \\
\stackrel{\sim}{\sim} \\
\sim\end{array}$ \\
\hline & $\hat{a}$ & $\begin{array}{l}\infty \\
\dot{\infty}\end{array}$ & શે & 0 & 0 & $\begin{array}{l}\mathscr{g} \\
i n\end{array}$ & 0 \\
\hline & $\begin{array}{l}\stackrel{0}{n} \\
\text { ni }\end{array}$ & $\frac{\pi}{\pi}$ & $\stackrel{\infty}{\underset{f}{f}}$ & $\begin{array}{l}0 \\
n \\
0 \\
0\end{array}$ & ñ & $\hat{n}$ & 0 \\
\hline & $\begin{array}{l}\dot{\sigma} \\
\text { a }\end{array}$ & \begin{tabular}{l}
$N$ \\
\multirow{2}{*}{}
\end{tabular} & $\vec{m}$ & $\begin{array}{l}n \\
i n\end{array}$ & $\stackrel{\text { to }}{\stackrel{1}{r}}$ & $\underset{\sim}{\stackrel{m}{*}}$ & $\begin{array}{l}\stackrel{J}{~} \\
\text { ¿ }\end{array}$ \\
\hline & $\stackrel{\Xi}{\stackrel{\Xi}{2}}$ & $\begin{array}{l}\text { to } \\
a\end{array}$ & 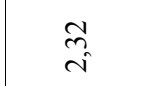 & $\stackrel{\infty}{\stackrel{\infty}{=}}$ & $\underset{\infty}{\infty}$ & $\begin{array}{l}\stackrel{2}{\partial} \\
\stackrel{2}{2}\end{array}$ & $\overrightarrow{8}$ \\
\hline & $\begin{array}{l}\text { Pे } \\
\text { in } \\
\text { n }\end{array}$ & $\begin{array}{l}\text { P } \\
\text { m }\end{array}$ & $\tilde{\tilde{o}}$ & 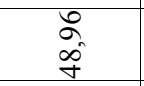 & $\begin{array}{l}1 \\
\delta \\
\text { On }\end{array}$ & $\hat{i}$ & $\underset{f}{\stackrel{7}{*}}$ \\
\hline & $\stackrel{n}{m}$ & 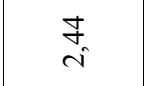 & $\begin{array}{l}8 \\
\circ\end{array}$ & $\frac{\vec{b}}{n}$ & $\begin{array}{l}\stackrel{+}{+} \\
\stackrel{2}{二}\end{array}$ & $\stackrel{8}{\circ}$ & $\stackrel{尺}{\beth}$ \\
\hline 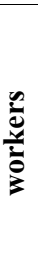 & 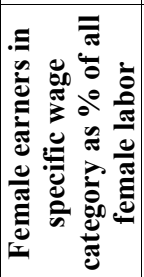 & 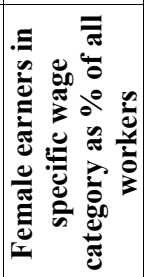 & 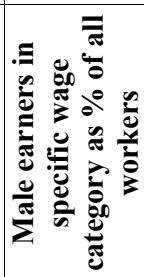 & 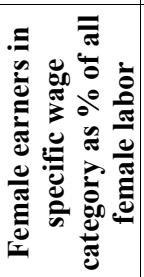 & 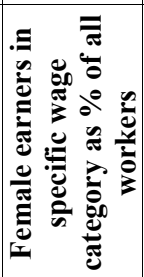 & 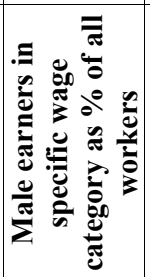 & 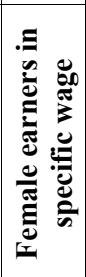 \\
\hline & 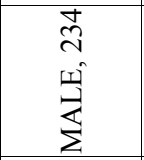 & 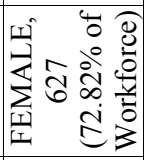 & & $\begin{array}{l}n \\
n \\
n \\
y \\
\vdots \\
\Sigma\end{array}$ & 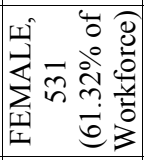 & & 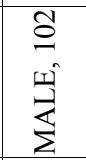 \\
\hline & $\simeq$ & & & $\nabla$ & & & $\hat{n}$ \\
\hline & 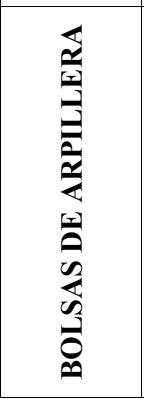 & & & 焉 & & & 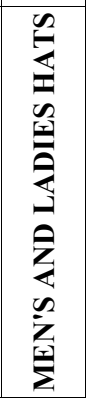 \\
\hline
\end{tabular}


ESTUDIOS ECONOMICOS

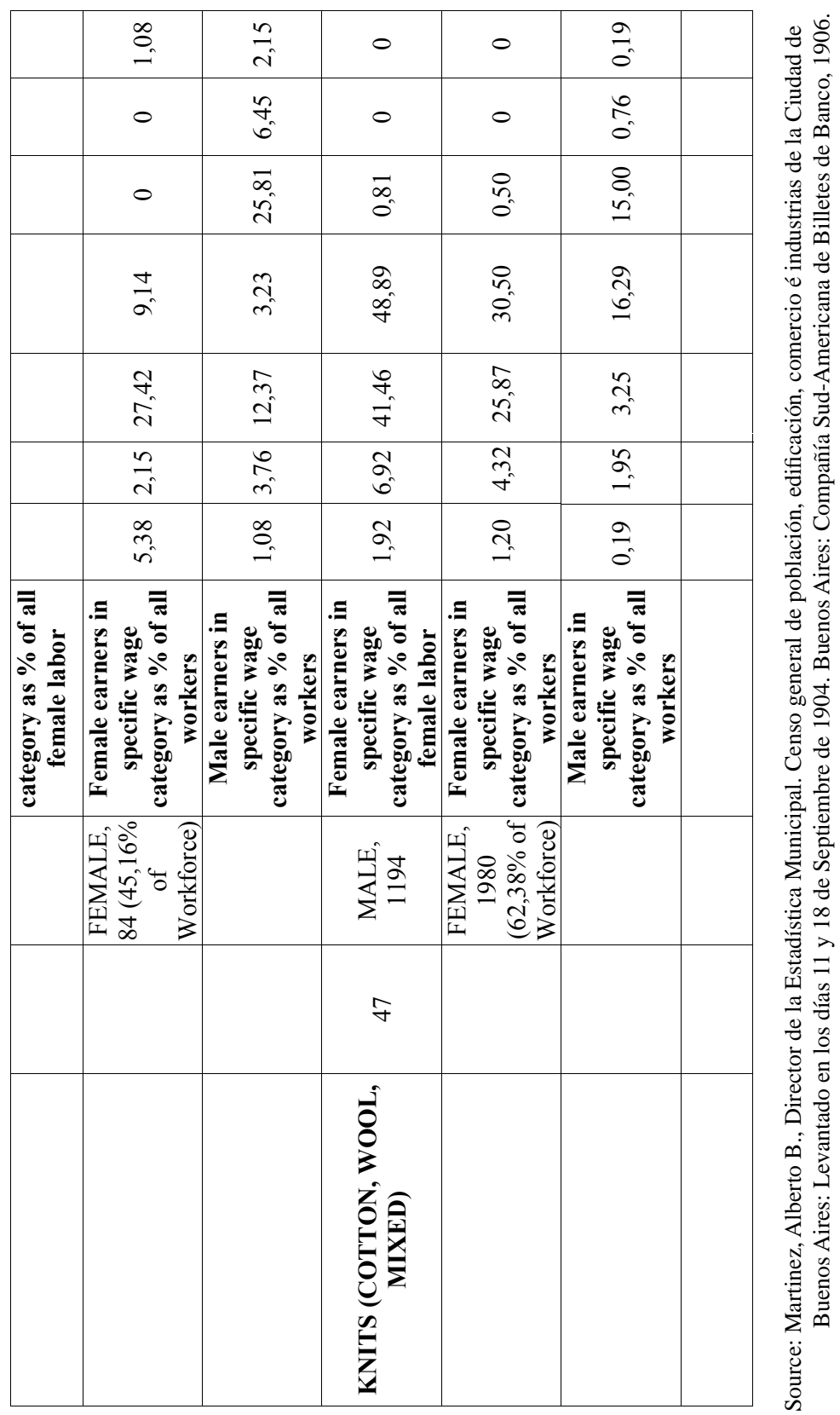




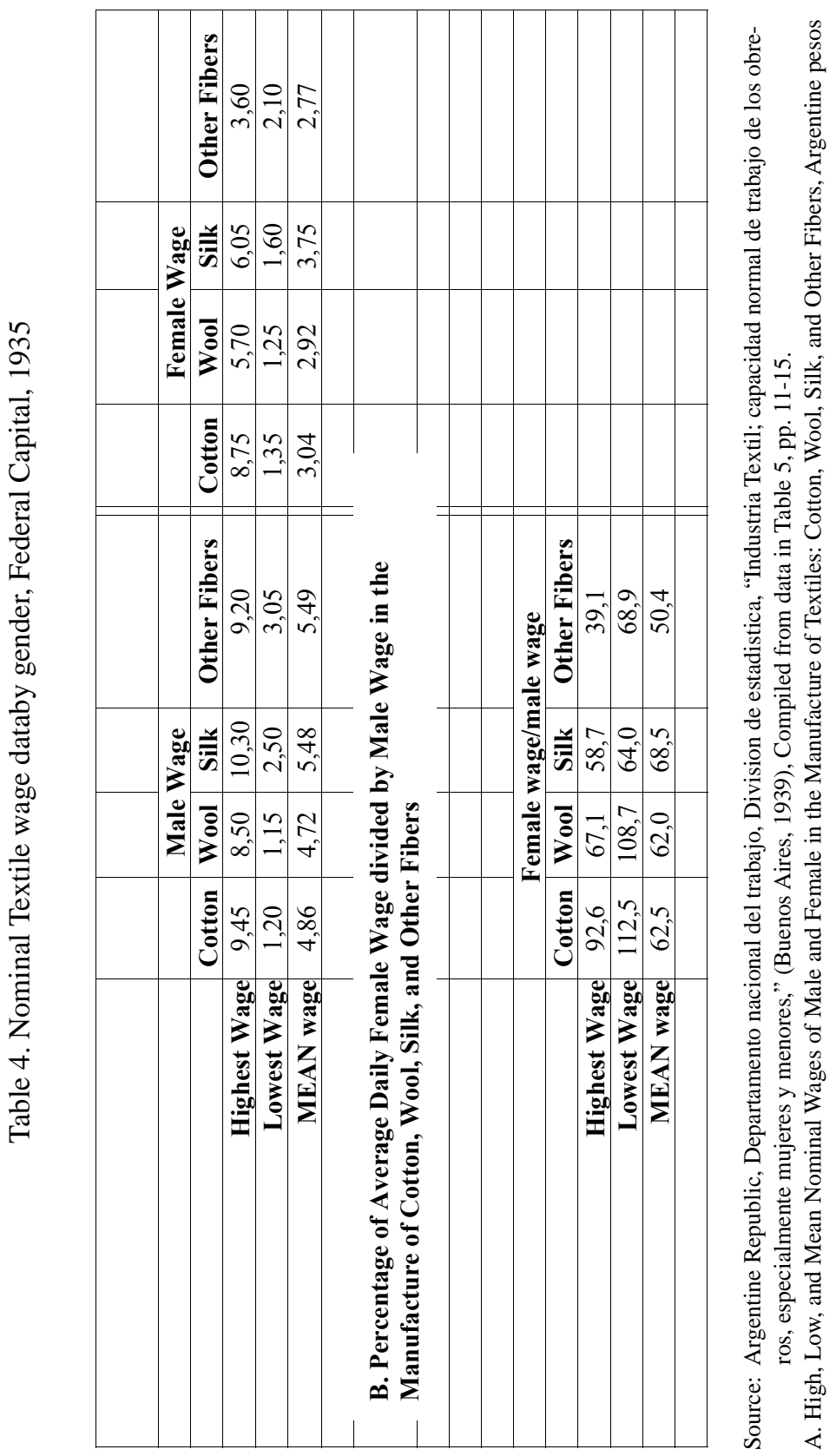




\section{WORKS CITED}

Data for this study were gleaned from census data, official government publications on labor wages and conditions, labor statistics collected over time by the Department of Labor, legislative proposals to protect women, labor legislation, and congressional debates and ministerial records on the question of female emancipation and work.

\section{PRIMARY SOURCES}

Argentine Republic, Departamento nacional del trabajo, División de estadística, "Industria Textil; capacidad normal de trabajo de los obreros, especialmente mujeres y menores”, Buenos Aires, 1939.

Bialet Massé, J., Informe sobre el estado de las clases obreras en el interior de la repúblic, Vol. 2, Buenos Aires: Imprenta y Casa Editora de Adolfo Grau, 1904, pp. 355-367.

Martinez, A. B., Director de la Estadística Municipal, Censo general de población, edificación, comercio é industrias de la Ciudad de Buenos Aires: Levantado en los días 11 y 18 de Septiembre de 1904, Buenos Aires: Compañía SudAmericana de Billetes de Banco, 1906.

Martinez, A. B., Censo general de población, edificación, comercio é industrias de la Ciudad de Buenos Aires: Conmemorativo del primer centenario de la revolución de Mayo, 1810-1910, Buenos Aires: Compañía Sud-Americana de Billetes de Banco, 1910.

Palacios, A. L., Legislación del Trabajo: Mujeres y Niños: Discursos del Diputado Palacios sobre la ley por el iniciada y sancionada por el congreso argentino. Buenos Aires: Imprenta Progreso, 1908.

Palacios, A., L., Por las mujeres y los niños que trabajan. Buenos Aires: F. Sempere y Compañía, 1912.

United States Department of Labor, Women Workers in Argentina, Chile, and Uruguay. Washington: Government Printing Office, 1942

United States, War Labor Policies Board, Report on International Labor Standards, Washington, D.C.: Government Printing Office, 1919

\section{II.SECONDARY SOURCES}

Belluci, M. and Camusso C., La huelga de inquilinos de 1907: El papel de las mujeres anarquistas en la lucha, Buenos Aires: Centro de Investigaciones 
en Ciencias Sociales, 1987.

French, J. D. and Daniel James, editors, The Gendered Worlds of Latin American Women Workers: From Household and Factory to the Union Hall and Ballot Box Durham: Duke University Press, 1997.

Guy, D. J. 'Women, Peonage and Industrialization: Argentina 1810-1914', Latin American Research Review, Vol. 16, (3), (1981), pp. 65-89.

Hutchinson, E. Q., Labours Appropriate to their Sex: Gender, Labor, and Politics in Urban Chile, 1900-1930, Durham: Duke University Press, 2001.

Lobato, M. Z., "La mujer trabajadora en el siglo XX: un estudio de las industrias de la carne y textile en Berisso, Argentina”, In Lobato, Mirta Zaida, Eliana Villar Márquez et al. Mujer, trabajo, ciudadanía. Buenos Aires: Gráficas y Servicios, 1995.

Lobato, M. Z., Historia de las trabajadoras en la Argentina (1869-1960), Buenos Aires: Edhasa, 2007.

Maier, Ch. S., "Between Taylorism and Technocracy: European ideologies and the vision of industrial productivity in the 1920s", Journal of Contemporary History, Vol. 5, (2) (1970), pp. 27-61.

Mercado, M. A., La primera ley de trabajo femenino, "La mujer obrera”, (18901910), Buenos Aires: Biblioteca Política Argentina, 1988.

Nari, M., Políticas de maternidad y maternalismo político en Buenos Aires, 18901940, Buenos Aires: Editorial Biblos, 2004.

Pinchbeck, I., Women Workers and the Industrial Revolution, 1750-1850, New York: Augustus M. Kelley, reprinted 1969.

Reich, M., Gordon D.M. and Edwards, R., 'A Theory of Labor Market Segmentation', American Economic Review, Vol. 63, (2), Papers and Proceedings of the $85^{\text {th }}$ Annual Meeting of the American Economic Association (May 1973) pp.359-365. 